\title{
RESEARCH METHODS AND DATA ANALYSIS TECHNIQUES IN EDUCATION ARTICLES PUBLISHED BY INDONESIAN BIOLOGY EDUCATIONAL JOURNALS
}

\author{
Ahmad Fauzi ${ }^{1 *}$ and Ika Wahyu Pradipta ${ }^{2}$ \\ ${ }^{1}$ Departement of Biology Education, University of Muhammadiyah Malang, East Java, Indonesia \\ ${ }^{2}$ Badan Pusat Statistik (BPS - Statistics Indonesia), Jakarta, Indonesia \\ *Corresponding e-mail: ahmad_fauzi@umm.ac.id
}

\begin{abstract}
The essential of studies which focus on research methods in biology educational field is providing recommendations for the next researchers the proper methods they need to use. Unfortunately, this kind of research is still hard to find in Indonesia. The aim of this study was to access the diversity of research approaches, designs, variables, data collection and analysis techniques, as well as research subjects in the articles published in Indonesian biology educational journals throughout 2017. Content analysis was used as the research design in this study in which as many as 122 articles were analyzed. The results revealed that the most type, design, variable, data collection and analysis techniques, as well as the subject which frequently used, were R\&D, Quasi-experimental, media/learning sources, questionnaire, frequency and percentage, and senior high school respectively. There were the variety of approaches, designs, data collection and analysis techniques, as considerable as research subjects which have been used in educational research. Moreover, there also findings that some several studies with the same research design applied different data collection and data analysis techniques. Thus, it is suggested to the next researchers to choose the most proper methods in conducting their researches.
\end{abstract}

Keywords: Biology educational research, data analysis, research method

(C) 2018 Department of Biology Education, FTTE, University of Muhammadiyah Malang, Indonesia

\section{INTRODUCTION}

Research activities in the education field are one of the indicators that can be used to assess the development of the education system in a country (Cai et al., 2017). This due to the important role of educational research in both in influencing policy in education and increasing knowledge for education practitioners (Goktas et al., 2012; Ion \& Iucu, 2015; Tseng, 2012). Some previous research reports in the education field are often used for the basis of educational improvement and to determine how education works in a variety of situations (Lodico, Spaulding, \& Voegtle, 2010). Furthermore, the educational research results also can be used as a foothold in educational reform (Goktas et al., 2012). In the other words, they often underlying curriculum changes in educational reform (Elken \& Wollscheid, 2016; Somekh \& Zeichner, 2009). Based on those considerable reasons, the educational research contribution need to be optimized.
Related to its frequency, research in education has reached its momentum in recent years. This condition is reflected in the rapidly increasing rate of educational research (Uzunboylu \& Asiksoy, 2014). This growth number of educational research is evident from the proliferation of scientific articles in the educational academic journals (Goktas et al., 2012). Uzunboylu and Asiksoy (2014) informed that from various studies published in various journals indexed by Turkish National Academic Network and Information Centre and EBSCO, learning methods and cognitive dimensions are the two research focuses most frequently studied. On the other hand, Gul and Sozbilir (2016) argued that the three subject matters most often chosen by biology education researchers published in journals indexed in Social Sciences Citation Index (SSCI) were learning, teaching, and attitude.

Research in education, like the other disciplines, is essentially a problem-solving activity which addresses problems, tests 
hypothesis, or explains phenomena based on certain research approaches, designs, and procedures (Christensen, Johnson, \& Turner, 2014; Leedy \& Ormrod, 2013). Similar to various topics or subject matters, the research methods used in educational research are also diverse. Compared to qualitative, the quantitative approach is more often used by researchers in the educational studies (Goktas et al., 2012). Furthermore, experimental, descriptive, correlational, case studies of comparative approaches and surveys research are some of the research methods often found in various educational research reports (Karadag, 2010). Meanwhile, research samples were also varied, not only based on educational level (e.g. elementary school and postgraduate) but also the diversity of subjects (e.g. student and teacher), as well as the data collection techniques such as test, questionnaire, interview, observation, and document analysis (Goktas et al., 2012; Karadag, 2010; Uzunboylu \& Asiksoy, 2014).

The diversity of approaches, methods, and data collection techniques led to variety of data analysis techniques employed in various research reports. Although Goktas et al. (2012) and Uzunboylu and Asiksoy (2014) informed descriptive analysis methods are the most commonly used data analysis techniques, yet various other techniques are also frequently used by various researchers. The examples of such analysis techniques are t-test, ANOVA, ANCOVA, correlation, regression, factor analysis, and nonparametric test (Karadag, 2010). Interestingly, even though data analysis techniques chosen are different, the studies use similar design and research procedure (Dimitrov \& Rumrill, 2003; Knapp \& Ohio, 2009; Liou, Peng, \& Peng, 2006).

Various systematic analyzes have been conducted in various educational journal articles. Such a study is essential because it informs researchers in the educational field about the latest status in educational research field clearly (Lin, Lin, \& Tsai, 2014). Moreover, with the increasing of research publication rate, researchers will more difficult to access, read, and understand the all papers, especially for novice researchers (Goktas et al., 2012). In addition, the analysis of research themes, study areas, as well as research methods ease the educational practitioners to understand and measure the characteristics and progress in education (Choi, Seo, \& Kim, 2016). However, such studies, particularly the studies which examine the diversity of educational research methods in Indonesian educational journals, are still hard to find. In Indonesia, there only four reports found discussed this topic (Rosana, 2016; Rustaman, 2012; Vebrianto, 2018; Zulkifli, Jekti, \& Ramdani, 2015). Nevertheless, the two reports did not review the research articles, but the final assignment and the student thesis (Vebrianto, 2018; Zulkifli et al., 2015). While the two other reports only explored the diversity of the research forms without reporting the presence frequency of any form of the study (Rosana, 2016; Rustaman, 2012). Furthermore, of the four reports, none conducted in Biology education, but chemical education (Vebrianto, 2018) and science education (Rosana, 2016; Rustaman, 2012; Zulkifli et al., 2015).

Similar to other countries, the writing of educational articles by education practitioners in Indonesia tend to increase. One area of education in Indonesia that often involves research activities in biological education. Various journals of biological education are also growing every year which in line with the number of articles published as well.

Trend analysis and studies that examine the diversity of biology education articles published in various Indonesian journals provide overview and tendency of research trends that pose the main characteristics of the focus of education in Indonesia. This research type contributes to demonstrate the identity of education as well as providing noticeable recommendations for the future researches (Choi et al., 2016). In addition, this content-analysis-method research is also expected to provide an overview and guidance for the novice researchers (Knapp \& Ohio, 2009; Lin et al., 2014) about what the most often research methods used in research education in the country (Keselman et al., 2014).

Based on the above explanations, it is crucial to conduct the content analysis of educational research articles. By conducting a survey of research methods in various articles published in various journals throughout 2017, this study purposed to access the diversity of methods, analytical techniques, as well as research subjects used by educational researchers whose articles were published in biological journals in Indonesia. In more detail, this study is designed to answer the following questions: 1) What the most often research approach used by researchers?; 2) What the most often research designs chosen?; 3) What the most frequent variables studied?; 4) What the most preferred 
data collection techniques?; 5) What the most often analytical techniques used to analyze the research data?; and 6) Which the most often research subjects studied by researchers?

This study has several aspects that distinguish it from some previous researches. First, this study was conducted on all educational articles published throughout 2017 in the all Indonesian biological journals indexed by Directory of Open Access Journals (DOAJ). Second, there are various points studied in this study which are various matters related to the designs and procedures of research on the subject chosen by the researchers. Third, the option categories in each aspect in this study are more diverse and detail compared to similar previous studies. Fourth, the articles studied were not limited in quantitative approach researches but also the quantitative one. However, the present study is limited in term of the articles analyzed were only which published by the Journal indexed by DOAJ in 2017 . Thus, the articles published in the non-DOAJ-indexed journals and those which issued before and after 2017 were not examined.

\section{METHOD}

This study was content analysis with a document scanning method used as the research method. In this study, the articles analyzed were downloaded from the websites of Biological Journals in Indonesia. To obtain a list of DOAJ indexed journals, the DOAJ website (https://doaj.org) was accessed and the word "Biologi" (Biology) was used as a keyword in the search. From these steps, 18 Indonesian biological journals were obtained. Furthermore, from 18 journals, only journals with the focus and scope of "education" were selected. At this step, eight journals were obtained: The list of these eight journals can be seen in Table 1 . Furthermore, all articles from all issues published in 2017 of the eight journals were downloaded and analysed.

Table 1. The list of journals used in this study

\begin{tabular}{|c|c|c|c|c|}
\hline No & Journal & Publisher & e-ISSN & Website \\
\hline 1 & $\begin{array}{l}\text { Bioedukasi (Jurnal } \\
\text { Pendidikan Biologi) }\end{array}$ & $\begin{array}{l}\text { University of } \\
\text { Muhammadiyah Metro }\end{array}$ & $2442-9805$ & $\begin{array}{l}\text { http://fkip.ummetro.ac.id/journal/i } \\
\text { ndex.php/biologi/index }\end{array}$ \\
\hline 2 & $\begin{array}{l}\text { Biosfer: Jurnal } \\
\text { Biologi dan } \\
\text { Pendidikan Biologi }\end{array}$ & Pasundan University & $2549-0486$ & $\begin{array}{l}\text { http://journal.unpas.ac.id/index.ph } \\
\text { p/biosfer }\end{array}$ \\
\hline 3 & $\begin{array}{l}\text { Biodidaktika: Jurnal } \\
\text { Biologi dan } \\
\text { Pembelajarannya }\end{array}$ & $\begin{array}{l}\text { Sultan Ageng Tirtayasa } \\
\text { University }\end{array}$ & $2527-4562$ & $\begin{array}{l}\text { http://jurnal.untirta.ac.id/index.ph } \\
\text { p/biodidaktika/index }\end{array}$ \\
\hline 4 & $\begin{array}{l}\text { Jurnal Pendidikan } \\
\text { Biologi Indonesia }\end{array}$ & $\begin{array}{l}\text { University of } \\
\text { Muhammadiyah Malang }\end{array}$ & $2527-6204$ & $\begin{array}{l}\text { http://ejournal.umm.ac.id/index.p } \\
\text { hp/jpbi/index }\end{array}$ \\
\hline 5 & $\begin{array}{l}\text { Jurnal Pendidikan } \\
\text { Biologi }\end{array}$ & State University of Malang & $2540-9271$ & $\begin{array}{l}\text { http://journal2.um.ac.id/index.php } \\
\text { /jpb }\end{array}$ \\
\hline 6 & $\begin{array}{l}\text { Biosaintifika: Journal } \\
\text { of Biology \& Biology } \\
\text { Education }\end{array}$ & State University of Semarang & $2338-7610$ & $\begin{array}{l}\text { https://journal.unnes.ac.id/nju/ind } \\
\text { ex.php/biosaintifika }\end{array}$ \\
\hline 7 & BioEdu & State University of Surabaya & $2302-9528$ & $\begin{array}{l}\text { https://jurnalmahasiswa.unesa.ac.i } \\
\text { d/index.php/bioedu }\end{array}$ \\
\hline 8 & $\begin{array}{l}\text { Bioma Jurnal Ilmiah } \\
\text { Biologi }\end{array}$ & $\begin{array}{l}\text { University of PGRI } \\
\text { Semarang }\end{array}$ & $2549-9890$ & $\begin{array}{l}\text { http://journal.upgris.ac.id/index.p } \\
\text { hp/bioma/index }\end{array}$ \\
\hline
\end{tabular}

There were six aspects analyzed in this research. As presented in Table 2, each article was reviewed and classified based on six aspects: (i) a research approach (5 categories), (ii) research design (19 categories), (iii) investigated variables (14 categories), (iv) data collection techniques (6 categories); (v) data analysis techniques (19 categories); and (vi) research subjects (9 categories). The categories used in this study were adapted from previous studies as well as from several research method books. Categories ( $i$ ) adapted from Leedy and Ormrod (2013) and Christensen et al. (2014); categories (ii) adapted from Leedy and Ormrod (2013) and Uzunboylu and Asiksoy (2014); categories (iii) adapted from Choi et al. (2016) and Lin et al. (2014); categories (iv) adapted from Uzunboylu and Asiksoy (2014); categories (v) adapted from Karadag (2010) and Uzunboylu and Asiksoy (2014); and categories (vi) adapted from Uzunboylu and Asiksoy (2014). 
The appearance of the various categories in each aspect of each article was recorded and positioned as the raw data in this study. Then, the raw data was converted as a percentage. Percentages describe the frequency of occurrence of a category on a particular aspect from 122 articles that had been analyzed.

\section{RESULTS AND DISCUSSION}

The background of the editorial board member, the focus of the journal, the research trend, as well as the educational characteristics of a country undoubtedly determine the types of articles published by educational journals of a country. In this study, a brief overview of it was examined. A total of 122 articles from eight journals of biology from Indonesia that published throughout 2017 have been subjected to content analysis in this study. By analyzing the various aspects of the published articles, this study was also expected to be used as information and guidance for researchers in the field of education.

Once analyzed, the 216 articles are composed of 94 Biology articles, 114 Biology Education articles, and 8 articles that combine Biology and Biology Education research. Therefore, 94 articles were not used in this study (research articles in the field of Biology), while the remaining 122 articles continued to be analyzed.

\section{Percentage of each research approach category}

The graph illustrating the percentage distribution of various research approaches used in the Biology education articles reviewed in this study is presented in Figure 1. Based on the graph presented in Figure 1, of the 122 articles analyzed, the majority of research is Research \& Development/R \& D (41, 8\%). Furthermore, the second and third positions are quantitative research $(30.3 \%)$ and qualitative research (13.9\%). Classroom action research/CAR $(6.6 \%)$ is the least rare. In addition, there are $7.4 \%$ of researches whose research approaches are not included and cannot meet the criteria for one of the four categories of research approaches.

Based on the research approach used, R \& D research has a greater frequency than other research approaches. This present study informs that the characteristics and trends of educational papers published in Indonesia are different from research articles published in other countries
(Goktas et al., 2012; Uzunboylu \& Asiksoy, 2014). Goktas et al. (2012) who conducted similar research in Turkey reported that the quantitative approach dominated educational research The report is in line with Uzunboylu \& Asiksoy (2014) report which also reports on the same country as Goktas report.

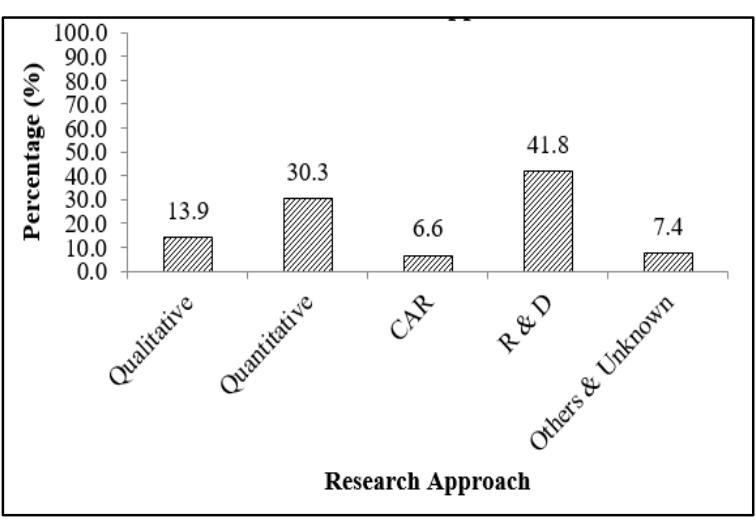

Figure 1. The distribution of biology education research based on the research approach

In this present study, the research approach was not only divided into two categories, qualitative and quantitative, because CAR and $\mathrm{R}$ $\& \mathrm{D}$ were positioned outside the two categories. With positioning, R \& D as its own category could provide information that, in Indonesia, $\mathrm{R}$ $\&$ D more often to be used than a qualitative or quantitative method. The high percentage of R \& $\mathrm{D}$ may be related to the trend in Indonesia where students are encouraged to publish their research in journals. In relation to that, not a few of Biology Education students whose research was originally pure research. However, because of the demands of the rules that their research should contain educational matter, the results of their pure research are used as a basis for developing media through $\mathrm{R} \& \mathrm{D}$. On the other hand, the smallest percentage indicate that CAR is less desirable by educational researchers today. Related to CAR, there is a new trend in CAR implementation in recent years. The trend is Lesson Study-based CAR that has been implemented in several studies (Buku, Mite, Fauzi, Widiansyah, \& Anugerah, 2015).

\section{Percentage of each research design category}

The selection of research design will serve as a guideline for how and where the research direction will be conducted (Grimshaw, Campbell, Eccles, \& Steen, 2000). In Figure 2, it can be seen, from 122 articles, some research articles do not mention the research design that was used. As many as $17.2 \%$ of the published 
articles cannot be categorized into one of the research design categories because they do not meet the characteristics of any research design, so the articles are categorized as "others \& unknown". In addition, CAR and R \& D has a research design of its own, so both are also raised as separate categories in the research design. Beyond these studies, quasi-experimental research $(12.3 \%)$ and pre-experimental research $(5.7 \%)$, were the most frequently used research designs. On the other hand, some other research designs, such as case studies, ethnography, phenomenological studies, descriptivedevelopment, ex-post facto, and meta-analysis are not found in articles published in 2017.

Table 2. Categories of research approach, design, variable, data collection techniques, data techniques analysis, and research subject

\begin{tabular}{|c|c|c|c|c|c|}
\hline No & Aspects & \multicolumn{4}{|c|}{ Categories } \\
\hline 1 & $\begin{array}{l}\text { Research } \\
\text { Approach }\end{array}$ & $\begin{array}{l}\text { A-Qualitative } \\
\text { B-Quantitative }\end{array}$ & $\begin{array}{l}\text { CAR } \\
\text { R\&D }\end{array}$ & & E-Others \& Unknown \\
\hline 2 & $\begin{array}{l}\text { Research } \\
\text { Design }\end{array}$ & $\begin{array}{l}\text { A.1-Case Study } \\
\text { A.2-Ethnography } \\
\text { A.3-Phenomenological Study } \\
\text { A.4-Action Research } \\
\text { A.5-Content Analysis } \\
\text { A6-Descriptive Qualitative } \\
\text { B.1-Descriptive Research Desig } \\
\text { Observation Studies } \\
\text { B.2-Descriptive Research Desig } \\
\text { Correlational Research } \\
\text { B.3-Descriptive Research Desig } \\
\text { Developmental Designs }\end{array}$ & & $\begin{array}{l}\text { B.4-Descr } \\
\text { Survey Re } \\
\text { B.5-Pre-E } \\
\text { B.6-True } \\
\text { B.7-Quasi } \\
\text { B.8-Ex Po } \\
\text { Research } \\
\text { Studies } \\
\text { C.1-Mixe } \\
\text { C.2-Meta- } \\
\text { C.3- Rese } \\
\text { D-Others }\end{array}$ & $\begin{array}{l}\text { tive Research Designs - } \\
\text { arch } \\
\text { erimental Designs } \\
\text { perimental Designs } \\
\text { ixperimental Designs } \\
\text { Facto Designs Descriptive } \\
\text { esigns - Observation } \\
\text { Methods Research } \\
\text { lalysis } \\
\text { ch and Development } \\
\text { Unknown }\end{array}$ \\
\hline 3 & $\begin{array}{l}\text { Research } \\
\text { Variable }\end{array}$ & $\begin{array}{l}\text { 1)-Assessment and Evaluation } \\
\text { 2)-Teacher Training } \\
\text { Programme } \\
\text { 3)-Learning Model/strategies } \\
\text { 4)-Media/learning sources } \\
\text { 5)-Learning Outcome }\end{array}$ & $\begin{array}{l}\text { 6)-T } \\
7)-\mathrm{M} \\
\text { 8)-S } \\
\text { skill } \\
\text { 9)-sc } \\
\text { 10)-1 }\end{array}$ & $\begin{array}{l}\text { kills } \\
\text { tion } \\
\text { process }\end{array}$ & $\begin{array}{l}\text { 11)-Curriculum } \\
\text { 12)-Misconception } \\
\text { 13)-Character } \\
\text { 14)-Others }\end{array}$ \\
\hline 4 & $\begin{array}{l}\text { Data Collection } \\
\text { Techniques }\end{array}$ & $\begin{array}{l}\text { a-Tests } \\
\text { b-Questionnaire }\end{array}$ & $\begin{array}{l}\mathrm{c}-\mathrm{Int} \\
\mathrm{d}-\mathrm{Dc}\end{array}$ & & $\begin{array}{l}\text { e-Observation } \\
\text { f-Others }\end{array}$ \\
\hline 5 & $\begin{array}{l}\text { Data Analysis } \\
\text { Techniques }\end{array}$ & $\begin{array}{l}\text { a.1-Descriptive analysis } \\
\text { a.2-Content analysis } \\
\text { a.3-Others Descriptive } \\
\text { analysis } \\
\text { a.4-Content analysis } \\
\text { a.5-Others } \\
\text { b.1-Illustrating with Graphics } \\
\text { b.2-Mean/SD }\end{array}$ & $\begin{array}{l}\text { b.3- } \\
\text { Freq } \\
\text { b.4-C } \\
\text { b.5-F } \\
\text { b.6-t } \\
\text { test } \\
\text { b. } 7-A \\
\text { b. } 8-A \\
\text { b.9-1 }\end{array}$ & $\begin{array}{l}\text { Percentage } \\
\text { ore/N-Gain } \\
\text { ample t-test } \\
\text { d sample t- } \\
\text { A } \\
\text { IA } \\
\text { VA } \\
\end{array}$ & $\begin{array}{l}\text { b.10-MANCOVA } \\
\text { b.11-Correlation } \\
\text { b.12-Regression } \\
\text { b.13-Factor analysis } \\
\text { b.14-Non-parametric } \\
\text { tests } \\
\text { b.15-Others } \\
\text { c.0-Did not mentioned }\end{array}$ \\
\hline 6 & $\begin{array}{l}\text { Research } \\
\text { subject }\end{array}$ & $\begin{array}{l}\text { o1-Lecturers } \\
\text { o2-Teachers } \\
\text { o3-Postgraduate Students }\end{array}$ & $\begin{array}{l}\text { o4-U } \\
\text { Stud } \\
\text { Teac } \\
\text { o5-S } \\
\text { Stud } \\
\text { o6-Ju }\end{array}$ & $\begin{array}{l}\text { aduate } \\
\text { e-service } \\
\text { igh School } \\
\text { igh School }\end{array}$ & $\begin{array}{l}\text { o7-Elementary School } \\
\text { o8-Families } \\
\text { o9-Others/did not } \\
\text { mention }\end{array}$ \\
\hline
\end{tabular}

Based on the research design, outside of $\mathrm{R} \&$ $\mathrm{D}$ and CAR, quasi-experimental research is the most common design found in articles published throughout 2017. However, this study also revealed that there were several studies that use similar approaches and research objectives, but have different research designs. This condition appears in several studies that compare two classes, controls and experiments, some research using true-experimental design (Ersanti \& Rahman, 2017; Faridah et al., 2017; Hariatik, Suciati, \& Sugiyarto, 2016), and the others using quasi-experimental design (Antika \& Nawawi, 2017; Aryanti \& Surtikanti, 2017; A. Rahmawati, Yayu, Hizqiyah, Biologi, \& Keguruan, 2017; Redhana \& Bestari, 2017; 
Rustininingsih, Saptasari, \& Dahlia, 2017; Shopia \& Mulyaningrum, 2017). Among the educational research designs, the trueexperimental design is a design to investigate the causes and effects in behavior (Leedy \& Ormrod, 2013). However, field conditions in educational studies prevent the possibility of researchers doing the random selection and random assignment of research subjects to be grouped into control and experimental groups (Liou et al., 2006). On the other hand, the quasi-experimental design is more often chosen because the design selection does not collide with practical and ethical barriers to conducting randomized controlled trials (Grimshaw et al., 2000).

In addition, in line with data obtained in research approaches aspect, in research design aspect, qualitative research designs were still rarely found in published articles. In fact, case studies, ethnography, and phenomenological studies were not found in the articles analyzed in this study. However, it does not mean that qualitative research has never been conducted in Indonesia. Several studies are qualitative descriptive research aimed at describing a lecture process in depth, such as some studies that describe the research project activity that conducted by undergraduate students on Genetics lectures (Fauzi, Corebima, \& Zubaidah, 2016; Fauzi \& Ramadani, 2017). In addition, there are also several descriptive studies that aim to describe the potential of model organisms as learning media of biology learning (Fauzi \& Corebima, 2016a, 2016b, 2016c). However, such research is still rarely conducted and published in Indonesia. This condition actually can be an opportunity for other prospective researchers to explore the realm of qualitative research in Indonesia. Moreover, the information derived from descriptive research can also be used as a basis for information to conduct R \& D. For example, Fauzi's research developed a project research guidebook for Genetics students after doing some descriptive research from the lectures (Fauzi, 2017).

\section{Percentage of each research variable category}

Various studies using various variables in the research. The diversity of those variables is presented in Figure 3. Based on the graph presented in Figure 3, it can be seen that studies that studying media or learning resources (30.8\%) were the most common studies. Furthermore, studies that examine strategies/learning model (17.6\%) and learning outcomes $(13.6 \%)$ occupy the second and third positions. On the other hand, there was no article that examines the curriculum. In addition, the teacher training program $(0.5 \%)$, assessment \& evaluation $(1.4 \%)$, and character $(1.4 \%)$ were the three research variables found most rarely in research articles throughout 2017.

In the aspects of research variables studied, educational articles published throughout 2017 vary widely. From the variety of these studies, the development of media or learning resources is the subject matter that most often found. This information is aligned with data on the research approach indicator where $\mathrm{R} \& \mathrm{D}$ is the most frequently published study. Generally, R \& D is a study aimed at developing media or learning resources. R \& D will likely remain the most popular research that found in various educational journals in Indonesia over the next few years. This prediction is based on publications in 2018 that also seem to describe such condition in 2017. One of the R \& D published in 2018 was research that develops Android-based media aimed at assisting students in the Zoology course (Widiansyah, Indriwati, Munzil, \& Fauzi, 2018).

\section{Percentage of each data collection techniques}

Various data collection techniques have been used in various research. From 122 articles analyzed, there were 247 data collection techniques that have been identified. According to the graph presented in Figure 4, the most frequently used data collection techniques were questionnaires $(36.8 \%)$, tests $(32.8 \%)$, and observations $(17.8 \%)$. Two other techniques that have the lowest percentage were interviews $(5.7 \%)$ as well as document analysis $(3.6 \%)$. The remaining $3.2 \%$ used other data collection techniques and some did not explain how the research data were obtained in the study.

\section{Percentage of each data analysis techniques}

The diversity of data analysis techniques used in articles that have been analyzed in this study is presented in Figure 5. Based on the graphs shown in Figure 5, the most commonly used data analysis techniques were frequency/percentage (32.2\%), mean/SD (18.8\%), and graphic illustrations (11.4\%). On the other hand, MANOVA, MANCOVA, and factor analysis are three data analysis techniques not found in any article. 


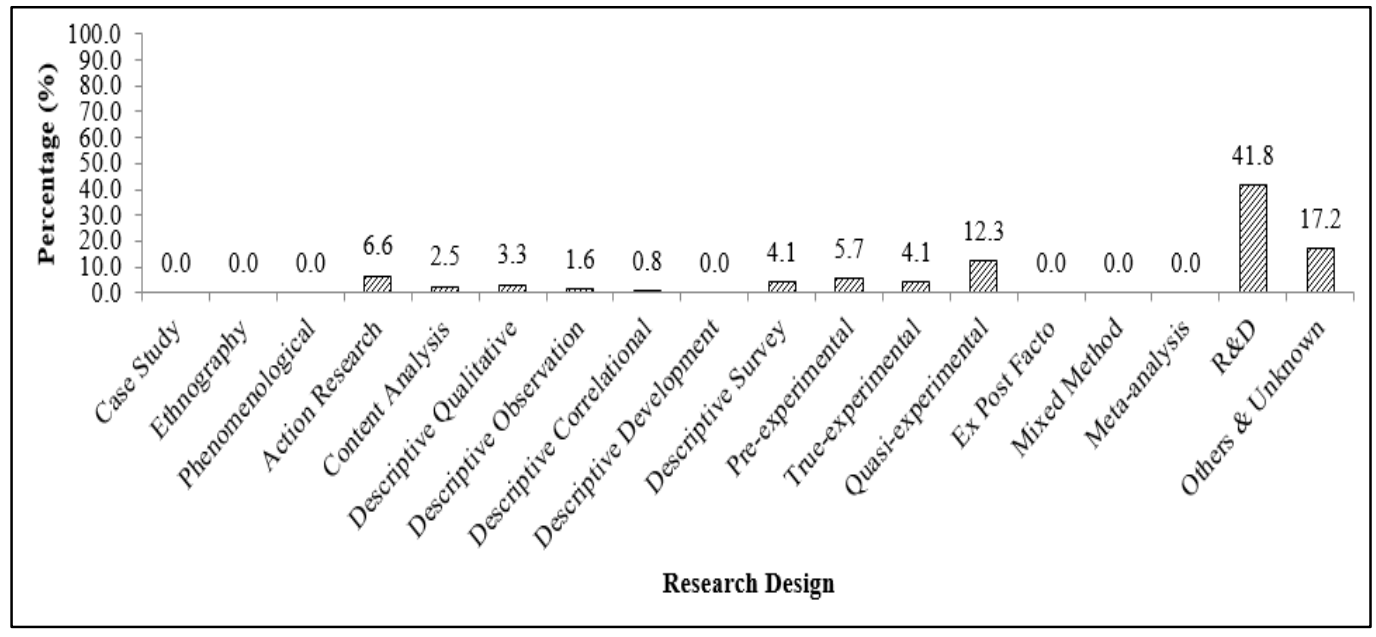

Figure 2. The distribution of biology education research based on research design

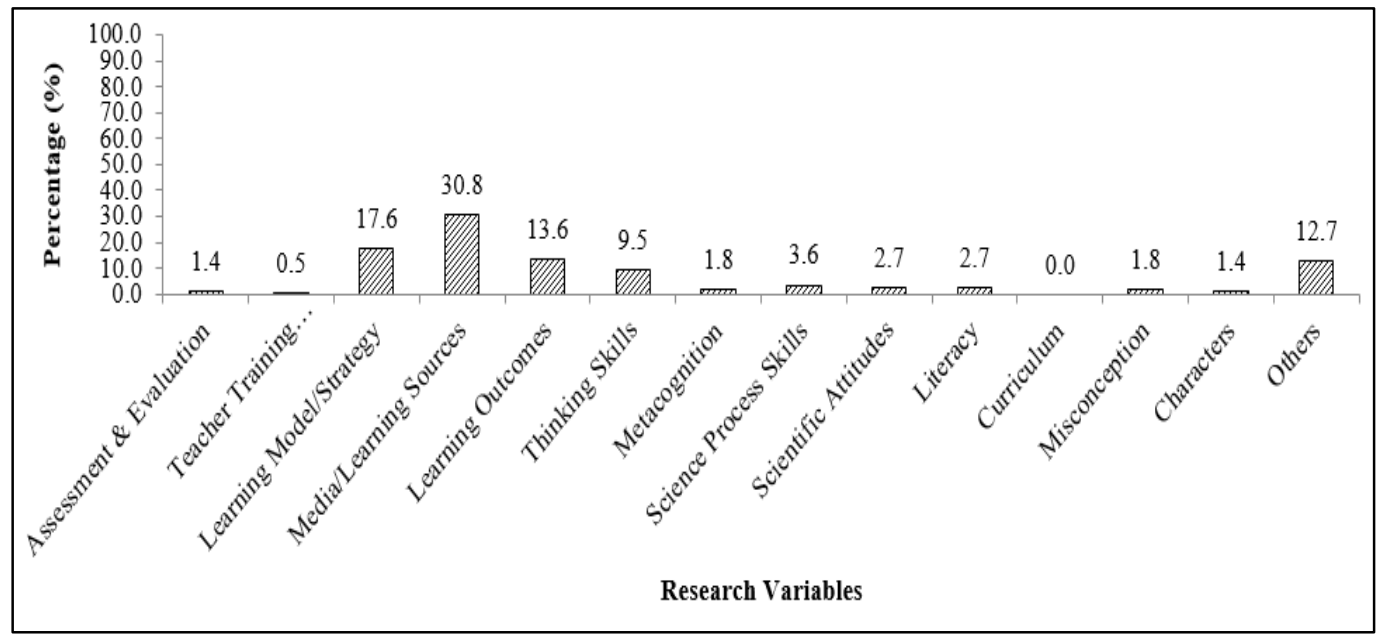

Figure 3. The distribution of biology education research based on research variables

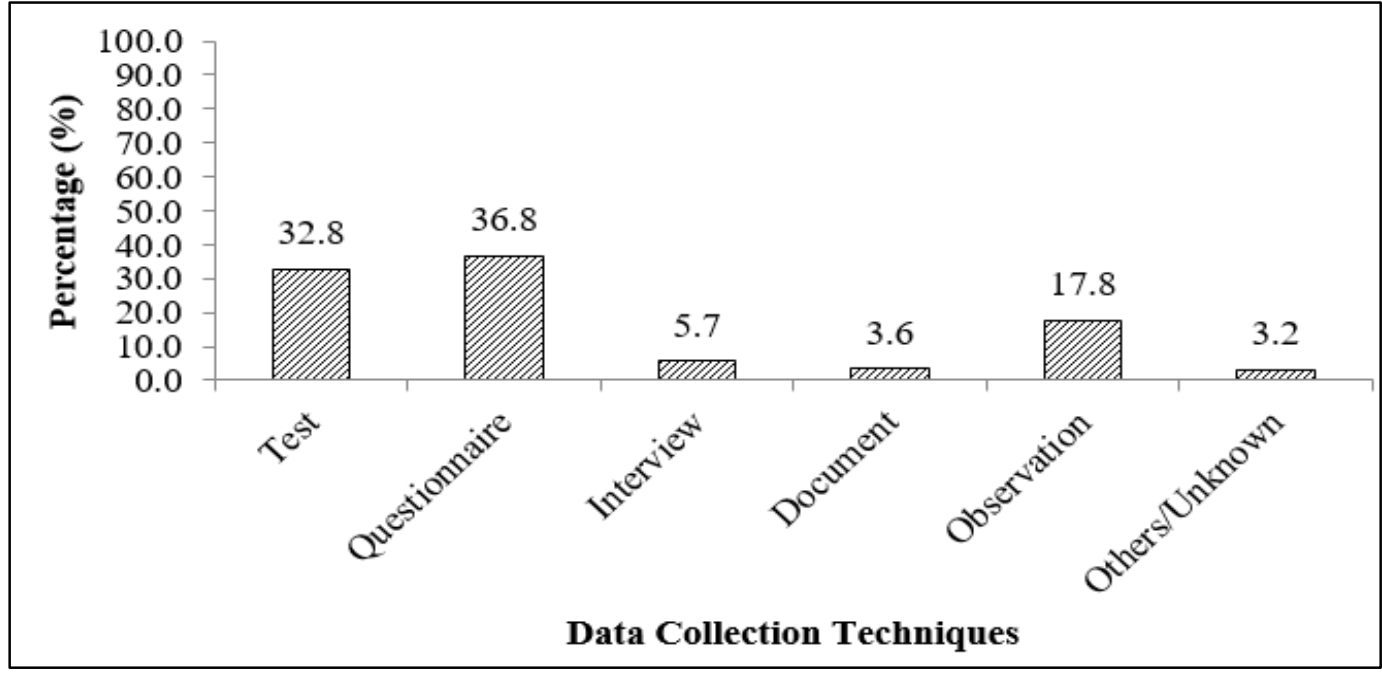

Figure 4. The distribution of biology education research based on data collection techniques

In the data collection and data analysis techniques, questionnaires, tests, and observations were the most popular techniques selected for data collection, while percentages, mean/SD, and interpretation using graphs were the most commonly used data analysis techniques. Thus, in general, the data obtained in the research were more often analyzed using descriptive rather than inferential statistics. The frequent selection of descriptive statistics as a technique of data analysis is in line with Karadag (2010). 


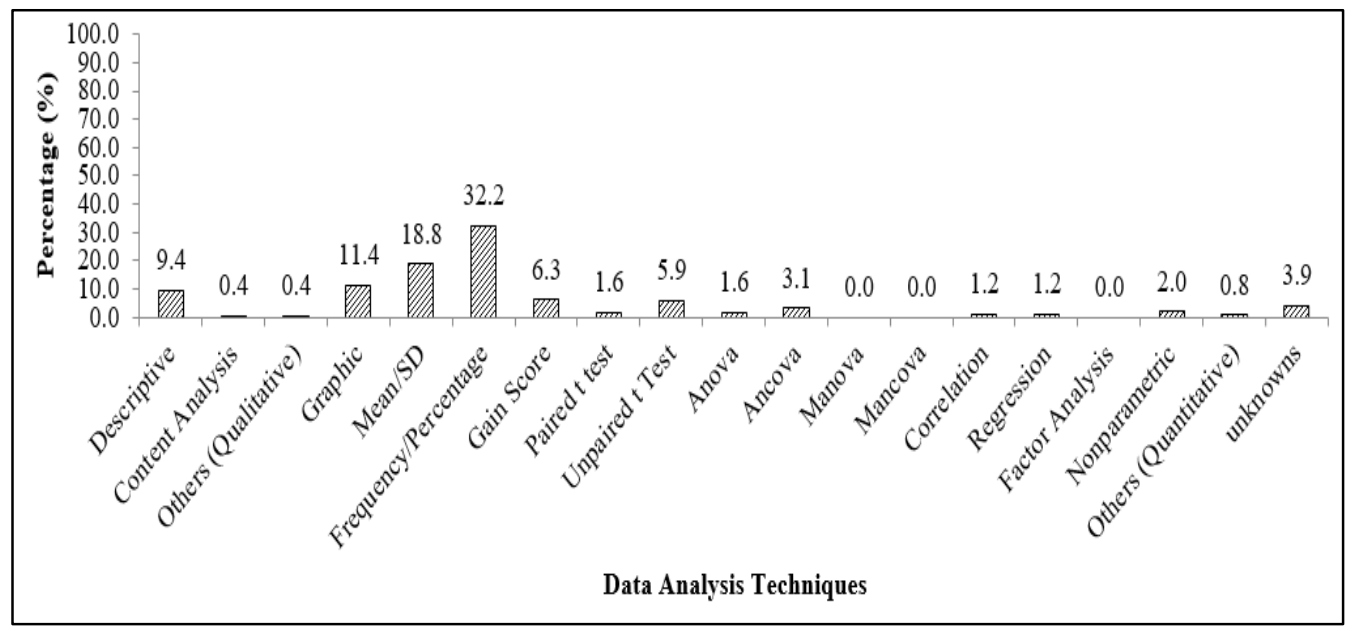

Figure 5. The distribution of biology education research based on data analysis techniques

\section{Percentage of each research subjects}

The focus of the study in Indonesia was not limited to the high school level. Various levels of education have been studied. The diverse subjects of the study in research articles that have been analyzed in this study are presented in Figure 6. According to the graph shown in Figure 6, of the 122 articles analyzed, the research subjects that most frequently used were high school students (59.8\%). After high school students, research subjects who occupied the second and third positions were undergraduate/pre-service teachers (26.2\%), then junior high school students (9.8\%). Lecturers and family were two subjects who are not used as samples in research articles published in 2017.

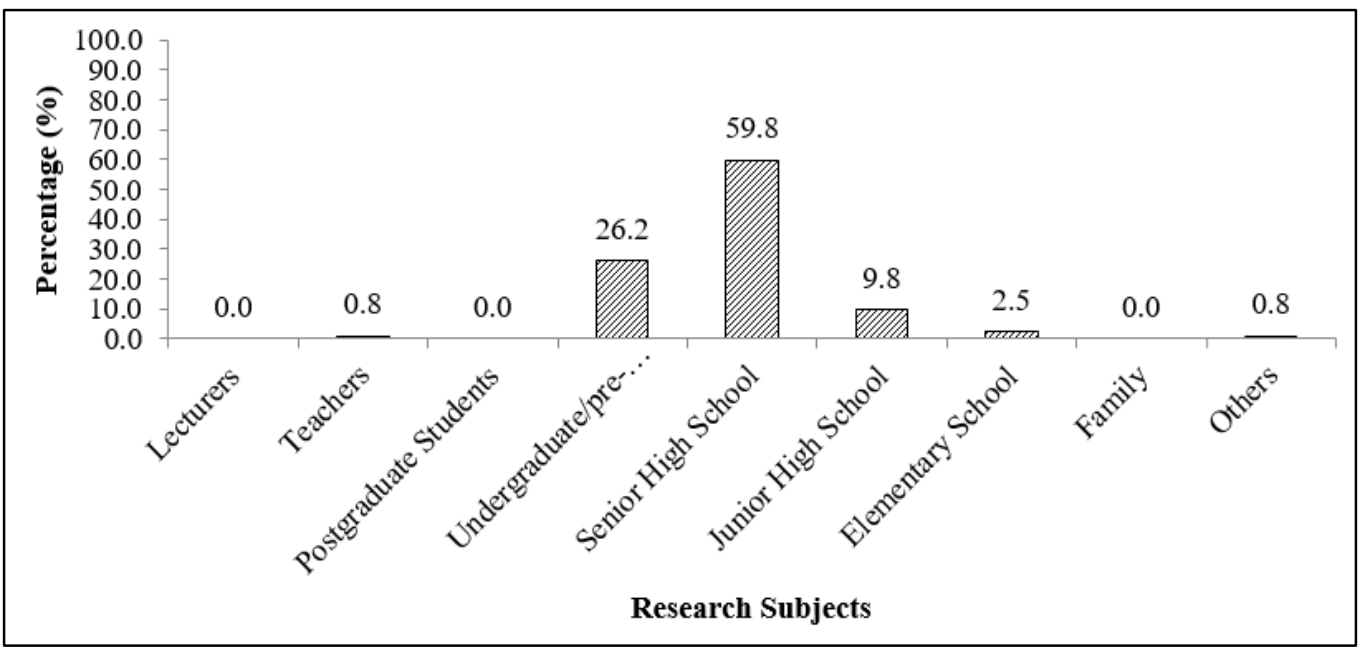

Figure 6. The distribution of biology education research based on research subjects

In this study also revealed that there were several studies of the same research design but have different data collection techniques and data analysis techniques. This condition appears in some studies with quasi-experimental design, some researchers only take posttest data (Shopia $\&$ Mulyaningrum, 2017), some other researchers not only take posttest data but also pretest data (Antika \& Nawawi, 2017; Aryanti \& Surtikanti, 2017; A. Rahmawati et al., 2017; Redhana \& Bestari, 2017; Rustininingsih et al., 2017; Toharudin, 2017). Furthermore, in the same study taking pretest and posttest data, the data analysis techniques used also vary. There is a study using descriptive statistics (Widodo, Maria, \& Fitriani, 2017), there is a study using gain score without a hypothetical test (Rustininingsih et al., 2017), there is a study using ANOVA or t-test only on posttest data (Kristiana, Nurwahyuni, \& Dewi, 2017), some were doing ANOVA or t-test on the gain score (Antika \& Nawawi, 2017; Toharudin, 2017), some were doing nonparametric test on the gain score (Aryanti \& Surtikanti, 2017; A. 
Rahmawati et al., 2017), and the others were using the ANCOVA (Redhana \& Bestari, 2017).

The controversy over the selection of data analysis on quasi-experimental research has been discussed several times (Knapp \& Ohio, 2009). In fact, the diversity of data analysis in quasi-experimental research is not limited to ANOVA with the gain score and ANCOVA on pretest-posttest data only, but also ANOVA on the residual score and repeated measures ANOVA (Dimitrov \& Rumrill, 2003). Referring to Knapp and Ohio (2009), gain scores are considered less reliable as well as gain score with negative correlation with a pretest. This is in line with Liou et al. (2006) and Dimitrov and Rumrill (2003) that ANCOVA is a more appropriate statistical technique in analyzing quasiexperimental data as long as the hypothesis test assumptions are met.

In addition, none of the research published in 2017 using multivariate analysis as a technique of data analysis. This current report is in line with the study of the doctoral dissertation at the education sciences in Turkey (Karadag, 2010) and the study on the biology education research article published in eight major academic journals indexed in SSCI (Gul \& Sozbilir, 2016) that report multivariate analysis was seldom used in educational research. Whereas in this content analysis, there were several quasiexperimental design studies that have more than one dependent variable. In fact, if there is more than one dependent variable but the researcher still uses the data analysis to analyze the dependent variable one by one, consequently the study may be less able to reach the research objective (Karadag, 2010; Patel, Padh, \& Bhavsar, 2017).

The diversity of data analysis techniques utilization also occurs in studies with the preexperimental design. There was research that uses only descriptive statistics or gain score as its data analysis technique (Aini \& Budijastuti, 2017; Diwaluthfi, Ibrahim, \& Fitrihidajati, 2017). On the other hand, there were also researchers who use paired sample t-test as a technique of data analysis (Jariyah, 2017; H. Rahmawati, Susantini, \& Wisanti, 2017; Rifqiawati, Wahyuni, \& Rahman, 2017).

The diversity of research design and data analysis techniques in studies with similar approaches and research procedures will provide problems for researchers who will conduct a meta-analysis in educational articles (Knapp \& Ohio, 2009). Therefore, some of the recommendations that can be given for future education research are as follows. First, if the research wants to see the effect of a treatment on one group, the researcher should take the data before and after treatment and then analyze it by using paired sample t-test. The reason, with this data analysis technique, researchers can ascertain whether there is a significant increase between before and after treatment. Second, in the research aimed at comparing two or more classes, the researcher should use quasiexperimental design. Third, if a study has the data before and after treatment of each group or class, then the study is more recommended to use an ANCOVA as statistical technique, rather than comparing the gain score using ANOVA. Finally, if the experimental research has more than one dependent variable, then a multivariate analysis should be chosen as a data analysis technique.

\section{CONCLUSION}

The study was a content analysis research of articles in biological education field published in journals indexed by DOAJ. There was a diversity of approaches, designs, variables, data collection techniques, data analysis techniques, and research subjects used in the various articles. $\mathrm{R}$ \& D was the most common research approach that found in published articles. Quasiexperimental research, media/learning sources, questionnaire, frequency and percentage, and senior high school were the most research design, variable, data collection techniques, data analysis techniques, and research subject that often be chosen. There also findings that some studies with the same research design applied different data collection and analysis techniques. Thus, it is suggested to the next researchers to choose the proper methods of conducting the researches.

\section{REFERENCES}

Aini, N., \& Budijastuti, W. (2017). Penerapan lembar kegiatan siswa berbasis penemuan terbimbing materi sistem ekskresi manusia untuk meningkatkan hasil belajar siswa kelas XI SMA. Bioedu, 6(2), 87-97.

Antika, R. N., \& Nawawi, S. (2017). Pengaruh model project based learning pada mata kuliah seminar terhadap keterampilan berpikir kreatif mahasiswa. JPBI (Jurnal 
Pendidikan Biologi Indonesia), 3(1), 72 79.https://doi.org/10.22219/jpbi.v3i1.3905

Aryanti, F., \& Surtikanti, H. (2017). Penerapan problem based learning (PBL) berbantuan teknologi informasi dan komunikasi untuk meningkatkan kemampuan berpikir kritis siswa pada konsep pencemaran lingkungan. Biosfer, Jurnal Biologi \& Pendidiikan Biologi, 2(1), 14-20. https:// doi.org/10.23969/biosfer.v2i1.370

Buku, M. N. I., Mite, Y., Fauzi, A., Widiansyah, A. T., \& Anugerah, D. Y. (2015). Penerapan pembelajaran coopera-tive script berbasis lesson study sebagai upaya peningkatan keaktifan lisan dan kecakapan sosial mahasiswa SI Pendidikan Biologi matakuliah strategi belajar mengajar. In Proceedings of the 2nd Seminar \& Workshop Nasional Biologi, IPA, dan Pembelajarannya FMIPA UM (pp. 603606). Malang: Biologi FMIPA UM.

Cai, J., Morris, A., Hwang, S., Hohensee, C., Robison, V., \& Hiebert, J. (2017). Improving the impact of educational research. Journal for Research in Mathematics Education, 48(1), 2-6. https ://doi.org/10.5951/jresematheduc.48.1.000 2

Choi, S. H., Seo, H. J., \& Kim, Y. S. (2016). Analysis of the research trends of the Korean journal of educational research using network text analysis. International Journal of Software Engineering and Its Applications, 10(12), 169-178. https://doi. org/10.14257/ijseia.2016.10.12.14

Christensen, L. B., Johnson, R. B., \& Turner, L. A. (2014). Research methods, design, and analysis, twelfth edition. New Jersey: Pearson.

Dimitrov, D. M., \& Rumrill, P. D. (2003). Pretest-posttest designs and measurement of change. Work 20, 20, 159-165.

Diwaluthfi, H., Ibrahim, M., \& Fitrihidajati, H. (2017). keefektifan LKS materi daur biogeokimia berbasis scientific approach terhadap kemampuan berpikir siswa kelas X SMA. Bioedu, 6(1), 9-13.

Elken, M., \& Wollscheid, S. (2016). The relationship between research and education: typologies and indicators.

Ersanti, K., \& Rahman, A. (2017). Implementation of fishbowl learning model on students of communication students on concept of environment pollution in class X SMAN 18 Tangerang regency. Biodidaktika, 12(2), 91-101.

Faridah, L. A., Sari, M. S., Pendidikan, J., Fakultas, B., Universitas, P., \& Malang, N. (2017). Pengaruh inkuiri dan PjBL bersumber potensi lokal terhadap pemahaman konsep, keterampilan proses sains, dan sikap ilmiah siswa. Jurnal Pendidiikan Biologi, 8(2), 38-45.

Fauzi, A. (2017). Analisis filogeni Tarsius tarsier form Buton dengan beberapa spesies tarsius dari Sulawesi Tengah, Sumatera-Kalimantan, dan Filipina atas dasar Gen MT-CO2 sebagai bahan pengembangan buku panduan penelitian Mata Kuliah Genetika II di Universitas Negeri Mal. Universitas Negeri Malang.

Fauzi, A., \& Corebima, A. D. (2016a). Fenomena gagal berpisah, epistasis, dan nisbah kelamin pada Drosophila melanogaster. In Seminar Nasional Biologi 2016 (pp. 283-288). Surabaya: Universitas Negeri Surabaya.

Fauzi, A., \& Corebima, A. D. (2016b). Pemanfataan Drosophila melanogaster sebagai organisme model dalam mempelajari Hukum Pewarisan Mendel. In Seminar Nasional Biologi 2016 (pp. 372377). Surabaya: Universitas Negeri Surabaya.

Fauzi, A., \& Corebima, A. D. (2016c). Pemanfataan Drosophila melanogaster sebagai organisme model dalam mengungkap berbagai fenomena penyimpangan rasio Mendel. In Seminar Nasional Biologi 2016 (pp. 278-282). Surabaya: Universitas Negeri Surabaya.

Fauzi, A., Corebima, A. D., \& Zubaidah, S. (2016). The utilization of ferns as a model organism for studying natural polyploidization concept in genetics course. In International Conference on Education (pp. 51-58). Malang: Universitas Negeri Malang.

Fauzi, A., \& Ramadani, S. D. (2017). Learning the genetics concepts through project activities using Drosophila melanogaster: a qualitative descriptive study. JPBI (Jurnal Pendidikan Biologi Indonesia), 3(3), 238-247. https://doi.org/10.22219/ jpbi.v3i3.4540

Goktas, Y., Hasancebi, F., Varisoglu, B., Akcay, A., Bayrak, N., Baran, M., \& Sozbilir, M. (2012). Trends in educational research in Turkey: A content analysis. Educational Sciences: Theory \& Practice, 12(1), 455- 
460.

Grimshaw, J., Campbell, M., Eccles, M., \& Steen, N. (2000). Experimental and quasiexperimental designs for evaluating guideline implementation strategies. Family Practice, 17(1), 11-18. https://doi. org/10.1093/fampra/17.suppl_1.S11

Gul, S., \& Sozbilir, M. (2016). International trends in biology education research from 1997 to 2014 : A content analysis of papers in selected journals. Eurasia Journal of Mathematics, Science \& Technology Education, 12(6), 1631-1651. https:// doi.org/10.12973/eurasia.2015.1363a

Hariatik, Suciati, \& Sugiyarto. (2016). Pembelajaran biologi model problem based learning (PBL) disertai dialog Socrates (DS ) terhadap hasil belajar ditinjau dari kemampuan memecahkan masalah kelas X. Jurnal Pendidikan Biologi, 8(2), 46-51.

Ion, G., \& Iucu, R. (2015). Does research influence educational policy? The perspective of researchers and policymakers in Romania. In A. Curaj, L. Matei, R. Pricopie, J. Salmi, \& P. Scott (Eds.), The European Higher Education Area: Between Critical Reflections and Future Policies (pp. 865-880). Cham: Springer International Publishing. https://doi.org/ 10.1007/978-3-319-20877-0_52

Jariyah, I. A. (2017). Efektivitas pembelajaran inkuiri dipadu sains teknologi masyarakat (STM) untuk meningkatkan kemampuan berpikir kritis pada mata pelajaran IPA. JPBI (Jurnal Pendidikan Biologi Indonesia), 3(1), 1-9. https://doi.org/10.2 2219/jpbi.v3i1.3888

Karadag, E. (2010). An analysis of research methods and statistical techniques used by doctoral dissertation at the education sciences in Turkey. Current Issues in Education, 13(4), 1-21.

Keselman, H. J., Huberty, C. J., Lix, L. M., Olejnik, S., Cribbie, R. A., Donahue, B., ... Levin, J. R. (2014). Statistical practices of educational researchers: An analysis of their ANOVA, MANOVA, and ANCOVA analyses. JSTOR, 68(3), 350-386. https://doi.org/10.2307/1170601

Knapp, T. R., \& Ohio, T. (2009). From gain score $t$ to ANCOVA F (and vice versa). Practical Assessment, Research \& Evaluation, 14(6), 1-7.

Kristiana, I., Nurwahyuni, A., \& Dewi, E. R. S. (2017). Pengaru model pembelajaran TGT menggunakan media puzzle terhadap keaktifan dan hasil belajar kogniti siswa pada materi sistem ekskresi. Bioma, 6(2), 78-92. https://doi.org/http://dx.doi.org/10. 26877/bioma.v6i2.1740

Leedy, P. D., \& Ormrod, J. E. (2013). Practical research: planning and design, tenth edition. New Jersey: Pearson.

Lin, T., Lin, T., \& Tsai, C. (2014). International journal of science research trends in science education from 2008 to 2012 : A systematic content analysis of publications in selected journals. International Journal of Science Education Publication, 36(8), 1346-1372. https://doi.org/10.1080/09500 693.2013.864428

Liou, S., Peng, C. J., \& Peng, C. J. (2006). The use Of hierarchical ANCOVA in curriculum studies. Journal of Modern Applied Statistical Methods, 5(1), 230247. https://doi.org/10.22237/jmasm/1146 457080

Lodico, M. G., Spaulding, D. T., \& Voegtle, K. H. (2010). Methods in educational research: from theory to practice, 2nd edition. San Francisco: John Wiley \& Sons, Inc.

Patel, S., Padh, H., \& Bhavsar, C. (2017). "MANOVA over ANOVA"-A better objective in bioequivalence study. International Journal Of Pharmaceutical Sciences And Research, 4(5), 1874-1881. https://doi.org/10.13040/IJPSR.09758232.4(5).1874-81

Rahmawati, A., Yayu, I., Hizqiyah, N., Biologi, J. P., \& Keguruan, F. (2017). Implementasi model pembelajaran prob-lem based learning untuk meningkatkan penguasaan defisiensi nutrisi tumbuhan pada mahasiswa Pendidikan Biologi Universitas Pasundan. Biosfer, Jurnal Biologi \& Pendidikan Biologi, 2(1), 21-25. https:// doi.org/http://dx.doi.org/10.23969/biosfer. v2i1.369

Rahmawati, H., Susantini, E., \& Wisanti. (2017). The effectiveness implementation of students' worksheets based on metacognitive strategy in materials of human inheritance to train the ability of students' metacomprehension. Bioedu, 6(2), 118-124.

Redhana, I. W., \& Bestari, N. D. D. (2017). Keunggulan komparatif buku pelajaran IPA SMP berbasis penalaran untuk meningkatkan hasil belajar siswa. 
Biodidaktika, 12(1), 48-58.

Rifqiawati, I., Wahyuni, I., \& Rahman, A. (2017). Pengaruh metode field trip dengan pemanfaatan rumpon buatan terhadap keterampilan proses sains dan sikap ilmiah di SMP Satu Atap Pulau Tunda. Biodidaktika, 12(1), 23-30.

Rosana, D. (2016). Analisis trend penelitian pendidikan sains. In Sutarno, Sukarsono, \& Martaningsing (Eds.), Prosiding Seminar Nasional: Optimasi Active Learning dan Character Building dalam Meningkatkan Daya Saing Bangsa di Era MEA (pp. 487495). Yogyakarta: Prodi PGSD dan Prodik BK FKIP UAD.

Rustaman, N. Y. (2012). Trend penelitian pendidikan: Kasus penelitian pendidikan sains. In Proceeding Seminar Nasional Pendidikan IPA: Peningkatan Kompetensi Profesionalisme Guru Sains Berkelanjutan Melalui Penelitian dan Publikasi Ilmiah (pp. 1-13). Bandung.

Rustininingsih, A., Saptasari, M., \& Dahlia. (2017). Pembelajaran biologi berbasis inkuiri untuk meningkatkan keterampilan metakognitif, pemahaman konsep, dan sikap ilmiah siswa kelas X SMA. Jurnal Pendidiikan Biologi, 9(1), 57-63.

Shopia, A., \& Mulyaningrum, E. R. (2017). Pengaruh model pembelajaran reciprocal teaching berbantu media pictorial riddle terhadap kemampuan berpikir kritis dan hasil belajar kognitif siswa. Bioma, 6(1). https://doi.org/10.26877/bioma.v6i1.1486

Somekh, B., \& Zeichner, K. (2009). Action research for educational reform: Remodelling action research theories and practices in local contexts. Educational Action Research, 17(1), 5-21. https:// doi.org/10.1080/09650790802667402

Toharudin, U. (2017). Meningkatkan pemaha- man konsep IPA dan keterampilan berinkuiri siswa sekolah dasar melalui pemanfaatan bahan ajar bernuansa literasi sains dalam model pembelajaran IPA terpadu. Biosfer, Jurnal Biologi \& Pendidiikan Biologi, 1(1), 23-32. https:// doi.org/http://dx.doi.org/10.23969/biosfer. v1i1.202

Tseng, V. (2012). The uses of research in policy and practice. Social Policy Report, 26(2).

Uzunboylu, H., \& Asiksoy, G. (2014). Research in physics education: A study of content analysis. Procedia-Social and Behavioral Sciences 136, 136, 425-437. https://doi. org/10.1016/j.sbspro.2014.05.353

Vebrianto, R. (2018). Trend tema penelitian tugas akhir mahasiswa Pendidikan Kimia FTK UIN SUSKA Riau (2006-2017): Sebuah kajian kasus. JNSI: Journal of Natural Science and Integration, 1(1), 110.

Widiansyah, A. T., Indriwati, S. E., Munzil, \& Fauzi, A. (2018). I-invertebrata as an android-based learning media for molluscs, arthropods, and echinoderms identification and its influence on students' motivation. JPBI (Jurnal Pendidikan Biologi Indonesia), 4(1), 43-52. https://doi.org/ 10.22219/jpbi.v4i1.5476

Widodo, A., Maria, R. A., \& Fitriani, A. (2017). Constructivist learning environment during virtual and real laboratory activities. Biosaintifika, 9(1), 11-18. https://doi.org/ 10.15294/biosaintifika.v9i1.7959

Zulkifli, L., Jekti, D. S. D., \& Ramdani, A. (2015). Analisis kecenderungan penelitian tesis mahasiswa pada Program Studi Magister Pendidikan IPA Universitas Mataram. Jurnal Penelitian Pendidikan IPA (JPPIPA), 1(1), 14-23. 